\title{
Lung status in young Danish rurals: the effect of farming exposure on asthma-like symptoms and lung function
}

\author{
Ø. Omland ${ }^{\star+}$, T. Sigsgaard*, C. Hjort*, O.F. Pedersen*, M.R. Miller
}

\begin{abstract}
Lung status in young Danish rurals: the effect of farming exposure on asthma-like symptoms and lung function. Ø. Omland, T. Sigsgaard, C. Hjort, O.F. Pedersen, M.R. Miller. (C) ERS Journals Ltd 1999.

ABSTRACT: The aim of this study was to assess the prevalence of asthma (selfreported) and relate this to lung function and factors associated with asthma in young farmers.

Two hundred and ten female and 1,691 male farming students together with 407 males controls were studied. Each subject underwent a medical interview; forced expiratory volume in one second (FEV1) and forced vital capacity (FVC) were recorded using a dry wedge spirometer. Histamine bronchial reactivity was measured using the Yan method. Skin prick testing was performed using inhalant allergens.

Nonsmokers had lower prevalence of asthma (5.4-10.8\%) than smokers (11.3$21.0 \%)(p<0.05)$. Females reported symptoms of asthma nearly twice as often as males. Sex, smoking and a family history of asthma/allergy were significantly associated with asthma. Controls had higher standardized FEV1 and FVC residuals than male students, both nonsmokers $(0.21$ and 0.24$)$ versus $(-0.06$ and -0.05$)$ and smokers $(0.29$ and 0.33$)$ versus $(-0.11$ and 0.13$)(\mathrm{p}<0.032)$. Bronchial hyperresponsiveness, asthma, siblings with allergy and working with cattle (controls only) were significantly associated with reduced lung function.

In conclusion, the prevalence of asthma was significantly related to smoking, female sex, family history of asthma and allergy. Whilst bronchial hyperresponsiveness was associated with reduced lung function and lung function was slightly reduced in the male farming students, there was no association found between occupational farming exposure and either lung symptoms or lung function.

Eur Respir J 1999; 13: 31-37.
\end{abstract}

Exposure to fumes and both organic and inorganic dusts represents an occupational hazard in farming. High concentrations of carbon dioxide, hydrogen sulphide and ammonia have been measured inside animal confinement buildings [1-4]. Analyses of the dust have revealed several compounds including animal-derived material such as dander, hair, saliva and urine $[5,6]$, bacteria $[7,8]$, endotoxin $[7,9,10]$, fungi $[8,11]$, spores $[9,12]$ and mites $[13$, 14]. Inhalation of these substances might result in cellular and immunological responses that could lead to lung diseases.

The prevalence of asthma in farming populations, studied in the northern part of Europe, has shown a range 2.1$32 \%$ [15-18]. Positive skin prick test [15], pig farming [16] and positive test to both storage and house dust mites [17] have been suggested as risk factors for asthma, and exposure to dusts, animals and fodder yeast have been reported as provoking factors for asthma in the farming population [18].

The influence of occupational exposure on lung function in agricultural workers has been studied in farmers working in dairy barns and mainly in swine confinement buildings. Most of the studies have been cross-sectional $[19,21-30]$ but some longitudinal studies have been published $[20,29,32]$. Dairy farming has been found to be associated with minor lung function changes both in the
*Dept of Environmental and Occupational Medicine, University of Aarhus, Denmark. ${ }^{+}$Dept of Occupational Medicine, Aalborg Regional Hospital, Denmark. tDept of Medicine, Selly Oak Hospital, University of Birmingham, UK.

Correspondence: $\varnothing$. Omland

Institute of Environmental and Occupational Medicine

University of Åarhus

University Park Bldg. 180

DK 8000 Aarhus C

Denmark

Fax: 4589426199

Keywords: Agriculture

asthma

epidemiology

farmers

lung function

occupational exposure

Received: November 201997

Accepted after revision April 221998

The study was supported by the Danish Medical Research Council, the Danish Agricultural Research Council, Helsefonden and the P.C. Petersens foundation.
UK [19] (forced expiratory volume in one second (FEV1)) and in Finland [20] (forced vital capacity (FVC)). In studies focusing on exposure from swine confinement buildings the results have been conflicting. No significant differences in lung function between pig farmers and controls were found in studies from the USA [21], France [22] and Sweden [23]. In a Norwegian study [24] values for FVC, FEV1 and peak expiratory flow (PEF) were higher among current pig farmers compared to other farmers, but the FVC and FEV1 in the pig farmers were lower than the values obtained from a Norwegian reference population. Data from Canadian [25-27] and Dutch [28] studies have also shown significant differences in lung function measurements between swine confinement workers and controls.

Studies from the USA [30, 31] have shown slightly lower measures of FEV1, FVC and forced mid-expiratory flow (FEF25-75\%) in swine confinement workers than controls, with a positive correlation between exposure to dust, ammonia and respirable endotoxin and lung function decrements over a work period. This effect was particularly noticeable after 6 yrs of exposure, however, the relationship between baseline pulmonary function and exposure were not strong [30]. In a subsample of farmers in a Danish cross-sectional study [29] the number of years in pig farming and bronchial hyperreactivity were significant 
predictors for decline in FEV1. Data from a 5-yr followup of the same study population [32] showed that the largest yearly decline in FEV1 was among pig farmers, but the decline was not significantly greater than in farmers with no animal or dairy production. Most of these epidemiological studies in farming populations have, with one exception [27], focused on farmers with long working experience $[15-26,28]$.

No studies so far have been designed to focus on the effect of farming exposure on lung symptoms and lung function in young persons. Young farmers were therefore studied as they entered the trade, and were recruited into a longitudinal study of the prevalence and incidence of asthma in farming. The aim of the study was to assess the prevalence of asthma in this group of young farmers, measure their lung function and investigate possible factors associated with asthma and low lung function in this group of young adults from rural areas.

\section{Materials and methods}

\section{Study subjects}

All 2,478 students in their second term at farming schools in Denmark in the period February 1992 to February 1994 were invited to participate. Of these, 2,004 (81\%) accepted, but $40(2 \%)$ failed to attend the initial examination. Only those subjects under 26 yrs of age were selected for further study so that a satisfactory match for rural male controls could be made. The final study population of farming students was 1,901 of whom 1,691 were males and 210 females.

The age and sex distribution did not differ between the 474 who refused to attend and the participants. A random sample of 162 of the 474 nonattendants were asked why they did not accept the invitation and, of the 144 replies, $75(52 \%)$ claimed that either the study had no interest or they gave no reason, with the second commonest reason in $26(16 \%)$ subjects being fear of blood sampling.

To obtain control subjects 967 conscripts into the army from three Danish counties in the spring of 1994 were invited to participate. Inclusion criteria were living in rural areas and no intention of a farming career. There were 592 $(61 \%)$ who agreed to participate and a random sample of 407 were included as controls. The study was approved by the Ethics Committee and all participants gave written consent.

\section{Methods}

A modified British Medical Research Council (MRC) questionnaire on respiratory symptoms [33] was used for the medical interview with additional questions on allergy, asthma, family history of allergy, smoking and occupational history. Every period of employment was registered with the duration of work, the type of job and the type of farm involved. Family allergy was diagnosed if two or more people among siblings or parents had an allergic disease. Asthma was diagnosed if the subjects answered yes to at least one of the group A questions and two of the group B questions in table 1.

FEV1 and FVC were recorded in accordance with American Thoracic Society guidelines [34] using a dry wedge spirometer (Vitalograph, Buckingham, UK). Predicted values for FEV1 and FVC were computed by means of multiple regression based on data on height $(\mathrm{H})$ in metres and age (A) from healthy nonsmokers in the study cohort aged 17-26 yrs. The computed equations with residual standard deviation (RSD) were for males:

$\mathrm{FEV} 1=4.874 \times \mathrm{H}-0.00936 \times \mathrm{A}-4.0214(\mathrm{RSD} 0.50)$
$\mathrm{FVC}=6.187 \times \mathrm{H}+0.01990 \times \mathrm{A}-6.2004(\mathrm{RSD} 0.58)$

For females:

$\mathrm{FEV} 1=4.651 \times \mathrm{H}+0.00370 \times \mathrm{A}-4.3767(\mathrm{RSD} 0.40)$

$\mathrm{FVC}=5.345 \times \mathrm{H}+0.02150 \times \mathrm{A}-5.3980(\mathrm{RSD} 0.49)$

The standardized residuals (SR) were calculated from the equation:

\section{(Variablemeasured-Variablepredicted)/RSD}

Bronchial responsiveness was measured using the method of YAN et al. [35] with calibrated DeVilbiss No 40 nebulizers (Somerset, PA, USA) delivering a cumulative dose of $1.44 \mathrm{mg}$ histamine, and spirometry was recorded using a pneumotachograph whose temperature and humidity was stabilized by use of a fan [36]. Subjects whose FEV 1 fell by $20 \%$ or more of the largest FEV1 recorded at baseline or after inhalation of $0.9 \%$ saline were considered as having bronchial hyperresponsiveness (BHR). Anyone receiving inhaled or oral corticosteroid treatment for asthma and pregnant females were excluded from the bronchial histamine provocation test.

A skin prick test (SPT) was performed to evaluate immediate allergic reaction to a panel of 10 common inhalant allergens (Soluprick ALK; ALK-Abello, Copenhagen, Denmark). The panel was extended with allergens from storage mites (Tyrophagus putrescentia, Acarus siro and Lepidoglyphus destructor), moulds (Alternaria alternata and Cladosporium herbarum), cow, pig and horse. The extracts were placed on the skin of the forearm in two columns $50 \mathrm{~mm}$ apart. The skin was penetrated with a lancet,

Table 1. - Questions on asthma

\begin{tabular}{|c|c|}
\hline Group A & Group B \\
\hline Have you been told by a doctor that you have asthma? & Do you ever have chest tightness? \\
\hline Do you have asthma? & Do you wake in the morning with chest tightness? \\
\hline Have you ever had asthma? & Do you wake up in the night with wheeze? \\
\hline Do you ever wheeze? & Do you cough when you wake up in the morning? \\
\hline & Do you wake in the morning with cough? \\
\hline & Do you wheeze by exposure to cold air? \\
\hline & Do you wheeze when you exercise? \\
\hline & Do you wheeze by exposure to pollen? \\
\hline & Do you wheeze by exposure to animals? \\
\hline & Do you use asthma drugs? \\
\hline
\end{tabular}


and after $10 \mathrm{~min}$ the test was read as the greatest diameter of any weal. Atopic status was diagnosed if the subject had either one or more positive SPT greater than the histamine reference, or had allergic asthma, allergic rhinitis or allergic dermatitis.

\section{Analysis}

Univariate analysis was undertaken for categoric variables using $\chi^{2}$ in the two by two table. For comparisons of continuous variables a t-test was performed. Multivariate analysis was undertaken with logistic regression for categoric variables and linear regression for continuous variables. The models contained independent explanatory variables to control for confounding factors. A p-value $<0.05$ was taken as significant.

\section{Results}

The demographic characteristics of the cohort are listed in table 2 . The female farming students were significantly older $(19.7 \mathrm{yrs})$ and their height $(169.6 \mathrm{~cm})$ significantly lower than both the male farming students $(18.3 \mathrm{yrs}$ and $181.9 \mathrm{~cm})$ and the male controls $(18.5 \mathrm{yrs}$ and $180.6 \mathrm{~cm})$, $(\mathrm{p}<0.01)$. The male farming students were slightly, but significantly $(p<0.01)$, taller and slightly, but significantly, younger $(p<0.01)$ than their control counterparts. The male farming students had significantly more previous experience in farming in general and in working with swine and cattle $(3.9,2.4$ and 2.1 yrs, respectively) compared to the female farming students $(2.5,1.4$ and $1.3 \mathrm{yrs}$, respectively, $\mathrm{p}<0.05)$ and both these groups had more experience than the controls $(0.8,0.4$ and 0.3 yrs, respectively, $\mathrm{p}<0.05)$. Smoking habits were generally the same in all groups, although there were significantly more exsmokers among the male farming students $(2 \%)$ than in the control group $(0.2 \%)(\mathrm{p}<0.05)$.

The prevalence of self-reported asthma is presented in table 3 together with the distribution of smokers and nonsmokers, with the few exsmokers being included in the nonsmoker groups. The prevalence of self-reported asthma was in the range 5.4-21.0\%, being highest among the smoking females and lowest among the nonsmoking male farming students. Both smoking and nonsmoking female farming students reported symptoms of asthma nearly twice as much as the males, but the differences were only statistically significant when all the female farming students were compared with their male counterparts $(\mathrm{p}<$
Table 3. - Self-reported asthma in the cohort)

\begin{tabular}{lccc}
\hline & $\begin{array}{c}\text { Female } \\
\text { students }\end{array}$ & $\begin{array}{c}\text { Male } \\
\text { students }\end{array}$ & $\begin{array}{c}\text { Male } \\
\text { controls }\end{array}$ \\
\hline $\begin{array}{l}\text { Smokers } \\
\text { Nonsmokers }\end{array}$ & $13(21.0)^{*,+}$ & $60(11.3)^{+}$ & $18(13.2)^{+}$ \\
$\mathrm{n}$ & $16(10.8)$ & $63(5.4)$ & $16(5.9)$ \\
\hline
\end{tabular}

Data are presented as numbers with percentages in parenthesis. *: $\mathrm{p}<0.05$ group $v s$. male farmers; ${ }^{+}: \mathrm{p}<0.05$ smokers $v s$. nonsmokers.

0.05). In all groups, the prevalence of self-reported asthma was approximately twice as high among the smokers than among the nonsmokers $(\mathrm{p}<0.05)$. The prevalence of both self-reported asthma and BHR with the distribution of smokers and nonsmokers is illustrated in table 4 . The prevalence was highest among the smoking male controls (3.7\%) and lowest among the nonsmoking male farming students $(1.1 \%)$. In smokers (both sex) the prevalence of both self-reported asthma and BHR (3.3\%) was twice as high as in the nonsmokers $(1.6 \%)(\mathrm{p}<0.05)$, whilst among the farming male students the prevalence was nearly three times as high when comparing smokers and nonsmokers $(p<0.05)$. Nonsmoking male controls had significantly higher prevalence of both self-reported asthma and BHR than their male farming counterparts. The mean frequency of the BHR among subjects with self-reported asthma was $27 \%$ (range $15.4-50.0 \%$ ) being highest among nonsmoking male controls and lowest among smoking female farming students.

Factors associated with self-reported asthma were analysed by use of a logistic regression model. The full model contained variables of exposure (years of farming experience in all and years of tending swine, cattle, both swine and cattle, animals other than swine and cattle and years of field work only), sex, being a farming student or control, having been raised on a farm, smoking habits and family history of allergy and asthma. Table 5 shows the variables that contributed significantly to the model. BHR and SPT were not included, owing to the possibility that they might act as intermediate variables between exposure and disease. Female sex was associated with self-reported asthma (odds ratio (OR) for males 0.493). Asthma was also highly associated with smoking (OR 3.786) and having a mother with asthma (OR 3.445), while having siblings with allergy or asthma or having a father with asthma were associated to a lesser extent (OR 1.581-1.969). None of the other exposure variables contributed significantly to the model.

Table 2. - Demographic characteristics of the cohort $(n=2,298)$

\begin{tabular}{|c|c|c|c|}
\hline & $\begin{array}{l}\text { Female students } \\
\quad(n=210)\end{array}$ & $\begin{array}{l}\text { Male students } \\
\quad(\mathrm{n}=1691)\end{array}$ & $\begin{array}{l}\text { Male controls } \\
\quad(\mathrm{n}=407)\end{array}$ \\
\hline Age yrs & $19.7 \pm 1.6$ & $18.3 \pm 1.3^{* *,+}$ & $18.5 \pm 0.9^{* *}$ \\
\hline Height $\mathrm{cm}$ & $169.6 \pm 7.0$ & $181.9 \pm 6.9^{* *,+}$ & $180.6 \pm 7.0^{* *}$ \\
\hline Normal yrs in agriculture & $2.5 \pm 2.5^{\#}$ & $3.9 \pm 2.6^{\#, *}$ & $0.8 \pm 1.8$ \\
\hline Normal yrs with swine & $1.4 \pm 2.1^{\#}$ & $2.4 \pm 2.7^{\#, \ldots}$ & $0.4 \pm 1.2$ \\
\hline Normal yrs with cattle & $1.3(2.5)^{\#}$ & $2.1(2.9)^{\#,+}$ & $0.3(1.3)$ \\
\hline Smokers n (\%) & $62(29.5)$ & $530(31.3)$ & $136(33.4)$ \\
\hline Exsmokers n $(\%)$ & $4(1.9)$ & $33(2.0)^{*}$ & $1(0.2)$ \\
\hline Nonsmokers n (\%) & $144(68.6)$ & $1128(66.7)$ & $270(66.3)$ \\
\hline
\end{tabular}

Data are presented as means \pm SD, except where indicated. Normal yrs: 45 weeks of work with $40 \mathrm{~h} \cdot \mathrm{week}^{-1}$. **: $\mathrm{p}<0.01$ groups $v s$. female farmers; ${ }^{+}$: $\mathrm{p}<0.01$ group $v$ s. controls; ${ }^{*}: \mathrm{p}<0.05$ group $v$ s. controls; ${ }^{\#}: \mathrm{p}<0.05$ groups $v s$. controls; ${ }^{*}: \mathrm{p}<0.05$ group $v s$. female farmers. 
Table 4. - Self-reported asthma with bronchial hyperresponsiveness in the cohort

\begin{tabular}{lccc}
\hline & $\begin{array}{c}\text { Female } \\
\text { students }\end{array}$ & $\begin{array}{c}\text { Male } \\
\text { students }\end{array}$ & $\begin{array}{c}\text { Male } \\
\text { controls }\end{array}$ \\
\hline Smokers & $2(3.3)^{*}$ & $17(3.2)^{*,+}$ & $5(3.7)^{+}$ \\
Nonsmokers & $4(2.7)$ & $13(1.1)$ & $8(3.0)^{\#}$ \\
$\mathrm{n}$ & 207 & 1682 & 407 \\
\hline
\end{tabular}

Data are presented as numbers with percentages in parenthesis *: $\mathrm{p}<0.05$ all smokers $v s$. all nonsmokers; ${ }^{+}: \mathrm{p}<0.05$ smokers $v s$. nonsmokers; ${ }^{\#}: \mathrm{p}<0.005$ group vs. male farmers.

Being a farming student or being raised on a farm had no association to self-reported asthma.

The lung function values in the cohort are shown in table 6. The FEV1 and the FEV1/FVC ratio for the male farming smoking students were significantly lower $(\mathrm{p}<$ $0.01)$ than those for the smoking controls. The female farming students had significantly lower values $(p<0.01)$ of FEV1 and FVC compared to the other groups, whereas the $\mathrm{FEV} 1 / \mathrm{FVC}$ ratio for the female nonsmoking farming students was significantly higher $(\mathrm{p}<0.01)$ compared to the nonsmoking males.

Table 7 presents the FEV1 and FVC data expressed as SR based on internal predicted values for females and males from the regression equations using the healthy nonsmokers in the cohort. The SR for FEV1 and FVC were significantly higher (suggesting better lung function) for both the nonsmoking and smoking controls compared to the nonsmoking and smoking male students $(\mathrm{p}<0.032)$. The SR for the male controls were significantly higher than those for the female students $(\mathrm{p}<0.042)$, but based on different regression lines.

An analysis of all smokers with self-reported asthma from the male students $(n=60)$ and male controls $(n=18)$ revealed a significantly $(\mathrm{F}=1.53, \mathrm{p}=0.032)$ lower $\mathrm{SR}$ for FEV1 among the male students $(-0.610)$ than among the male controls (0.003). Nonsmoking male students with self-reported asthma $(n=63)$ also had a lower SR for FEV1 $(-0.348)$ than the male nonsmoking controls with selfreported asthma $(n=16)(-0.113)$, but the reduction was not significant $(\mathrm{p}=0.459)$. Factors associated with a lower SR for FEV1 and FVC were analysed by the use of multiple linear regression. The initial model contained variables of exposure (years of farming experience in all and years of tending swine, cattle, both swine and cattle, animals other than swine and cattle and years of field work only), sex,

Table 5. - Factors associated with self-reported asthma in the cohort. Logistic regression analysis, $n=2,286$

Odds ratio

(95\% confidence intervals)

\begin{tabular}{|c|c|}
\hline Mother with asthma & $3.445(2.092-5.673)$ \\
\hline Father with asthma & $1.969(1.083-3.580)$ \\
\hline Siblings with allergy & $1.690(1.070-2.670)$ \\
\hline Siblings with asthma & $1.581(1.040-2.403)$ \\
\hline $\begin{array}{l}\text { Smoking (10-19 cigarette } \\
\text { equivalents } \cdot \text { day }^{-1}\end{array}$ & $1.681(1.164-2.427)$ \\
\hline $\begin{array}{l}\text { Smokers }(>19 \text { cigarette } \\
\text { equivalents } \cdot \text { day }^{-1}\end{array}$ & $3.786(2.531-5.664)$ \\
\hline Sex & $0.493(0.318-0.765)$ \\
\hline$\%$ GM (Basic odds) & $0.093(0.060-0.143)$ \\
\hline
\end{tabular}

GM: grand mean. being a farming student or control, having been raised on a farm, smoking habits, family history of allergy and asthma, asthma, BHR, work-related symptoms of cough and chest tightness, number of positive SPT, positive SPT to house dust mite and positive SPT to storage mites.

Table 8 presents those variables that contributed significantly to the model. No factors significantly associated with reduced SR in FEV1 and FVC could be detected among the females and no exposure variables was associated with reduced SR for FEV1 and FVC among the male farming students. Asthma $(\mathrm{p}=0.036)$ and BHR $(\mathrm{p}<0.0001)$ were found to be factors significantly associated with reduced SR in FEV1 in the group of male students. In the control group, BHR was a factor associated with reduced SR in FEV1 $(p=0.014)$ and FVC ( $p=0.026)$, and siblings with allergy $(\mathrm{p}=0.047)$, and working with cattle $(\mathrm{p}=0.049)$ were factors associated with reduced SR in FVC. BHR was the most important factor associated with reduced SR for FEV1 and FVC. Neither smoking nor positive SPT reactions were factors significantly associated with reduced lung function.

\section{Discussion}

Prevalence figures for asthma from rural communities have been in the range $2.1-32 \%$ [15-18]. However, the populations in these studies have been older and more experienced in farming than the present cohort. Cumulative incidence data of asthma or wheezy bronchitis in the UK [37] were higher than the prevalence data in the present study, 24.5 and $28.6 \%$ by the ages of 16 and $23 \mathrm{yrs}$, respectively, and the prevalence of asthma among nonHispanic white females at a mean age of 26 yrs (SD 5) were similarly high at $30 \%$ [38]. These studies indicate that the prevalence of asthma found in the current study (from $5.4 \%$ amongst nonsmoking male farming students to $21.0 \%$ amongst smoking female farming students) is not especially high.

Smoking, female sex and a family history of asthma and allergy were found to be significantly associated with self-reported asthma. NEUKIRCH et al. [39] did not find any relation between asthma and sex among persons aged 2044 yrs, but there was an inverse relation to age. In contrast to these findings, studies from the UK [37] and the USA [40] found the same sex ratio as was found in the present study and in a Swedish study [41] on the incidence of asthma female sex and smoking were risk factors. VESTERINEN et al. [42] found results similar to those presented here. The prevalence of asthma was higher in both female and male smokers than in nonsmokers, however, these were only significantly higher in males. DAVID et al. [38] found that parental history of asthma as well as active cigarette smoking were strongly associated with wheeze syndromes. The range of the frequency of BHR among subjects with self-reported asthma was similar to observations in other studies [43]. The same difference in prevalence between smokers and nonsmokers was observed when analysing for self-reported asthma with BHR as for self-reported asthma alone, whilst the sex difference did not remain. These data strengthen the association between smoking and asthma, but weaken the sex association. The latter might be owing to a sex difference in morbidity or reporting. The interpretation of these findings using more 
Table 6. - Lung function measurements in the cohort $(n=2,296)$

\begin{tabular}{|c|c|c|c|c|c|c|}
\hline & \multicolumn{2}{|c|}{ Female students } & \multicolumn{2}{|c|}{ Male students } & \multicolumn{2}{|c|}{ Male controls } \\
\hline & Nonsmokers & Smokers & Nonsmokers & Smokers & Nonsmokers & Smokers \\
\hline $\mathrm{n}$ & 147 & 60 & 1152 & 530 & 271 & 136 \\
\hline FEV1 L & $3.59 \pm 0.51^{+}$ & $3.51 \pm 0.48^{+}$ & $4.64 \pm 0.60$ & $4.58 \pm 0.57 * *$ & $4.70 \pm 0.65$ & $4.75 \pm 0.59$ \\
\hline FVC L & $4.10 \pm 0.62^{+}$ & $4.04 \pm 0.58^{+}$ & $5.42 \pm 0.70$ & $5.49 \pm 0.67$ & $5.50 \pm 0.78$ & $5.57 \pm 0.69$ \\
\hline $\mathrm{FEV} 1 / \mathrm{FVC} \times 100$ & $88.0 \pm 6.5^{+}$ & $87.2 \pm 5.6$ & $85.9 \pm 6.4^{\#}$ & $83.8 \pm 6.9^{* *}$ & $85.8 \pm 6.5$ & $85.5 \pm 6.1$ \\
\hline
\end{tabular}

Data are presented as mean $\pm \mathrm{SD}$, except where indicated. $\mathrm{FEV} 1$ : forced expiratory volume in one second; FVC: forced vital capacity. $* *$ : $\mathrm{p}<0.01$ group $v$. controls; ${ }^{+}: \mathrm{p}<0.01$ groups $v$ s. males; ${ }^{\#}: \mathrm{p}<0.01$ group $v s$. smoking male students.

restricted criteria for the outcome variable should be taken with caution owing to the few number of observations.

The data from this study do not support the findings from another Danish study [16] where pig farming was a risk factor for asthma (OR 2.03). This is most probably due to differences in the subjects' ages and the length of exposure between the two studies. It is recognized that there might be a healthy worker selection in this study of young farming students, leading to a drop out of the symptomatic students. This might particularly be the case whilst working in swine confinement buildings and dairy barns where the concentration of animals is high and the exposure to organic dust is marked. The prevalence figures for asthma might therefore be underestimated due to selection out of work and into the rural control group.

Baseline lung function was slightly but significantly lower in male farming students compared to the male controls. The findings of the present study are similar to the measured differences in lung function from studies on the exposure effect of dairy farming $[19,20]$ and pig farming [25-28, 30, 31] on lung function, but different from data published from USA [21], France [22] and Sweden [23]. This heterogeneity in results might be due to real difference in exposure and susceptibility, but it might also be due to misclassification, healthy workers effect and small study populations resulting in low statistical power. If the findings of the present study indicate a rapid effect of farming on lung function, then the time for it to take effect is much shorter (2.5-3.9 normal yrs) than the duration of exposure reported in the previous studies (9.6-28 yrs expressed as mean or average) $[25-28,30,31]$. No data concerning the length of farming exposure are described in studies from the UK, Finland and Norway [19, 20, 24], but the age of the study subjects (mean age 44.2-46.9 yrs) indicates a longer time of farming exposure than in the present study.

The lung function data from the present study showed the expected sex differences being in agreement with the 1993 European Respiratory Society (ERS) reference values [44]. The FEV1 and FVC of the female farming students were significantly higher than the values from a random sample of matched controls from the centre of
Copenhagen [45] and healthy workers selection could be the explanation for this. Farming still needs physical strength in daily work operations thus favouring well-built and well-trained persons with sufficient lung function to meet the demands. This may be particularly the case for females. Whilst it was found in the male but not the female farming students that asthma and BHR were related to lower lung function results, only the negative finding in the females may be a type 2 statistical error. Studies from other rural communities have shown an impact of smoking on FEV1 $[30,32], \mathrm{FEV} 1 / \mathrm{FVC}$ and FEF25-75\% [46]. The populations in these studies have been older than the current cohort with a longer exposure to smoking. As there is a known dose-response relationship between smoking and change in FEV1 [47] this may account for why these students did not show a smoking-related decline in FEV1.

Asthma was modestly, but significantly, associated with a lower SR for FEV1 among male farming students, but not among the male controls. The prevalence of asthma was the same in the two groups and smoking habits were nearly the same. A possible answer to this observation could be differences in the working environment. Farming involves exposure to fumes and inorganic and organic dust that might additionally contribute to the asthmatic airway obstruction. The analysis of male asthmatics supports this argument.

In the present study, BHR was most strongly associated with reduced lung function for both SR in FEV1 and FVC and these data are in accordance with data from population based studies [48] and selected populations [29, 49, 50].

It was found that having siblings with allergy was associated with reduced SR in FVC among male controls. The reason for this may be due to genetic factors. It has been observed that total blood eosinophil count is inversely related to the level of FEV1 [51] and one might argue that there is an increased risk of having a high eosinophil count if siblings have allergy.

In contrast to the present study, other Danish studies [29, 32] have shown an association between a low level of FEV1 and the number of years in pig farming and bronchial hyperreactivity. The most likely explanation for this

Table 7. - Standardized residuals (SR) for forced expiratory volume in one second (FEV1) and forced vital capacity (FVC) in the cohort $(n=2,294)$

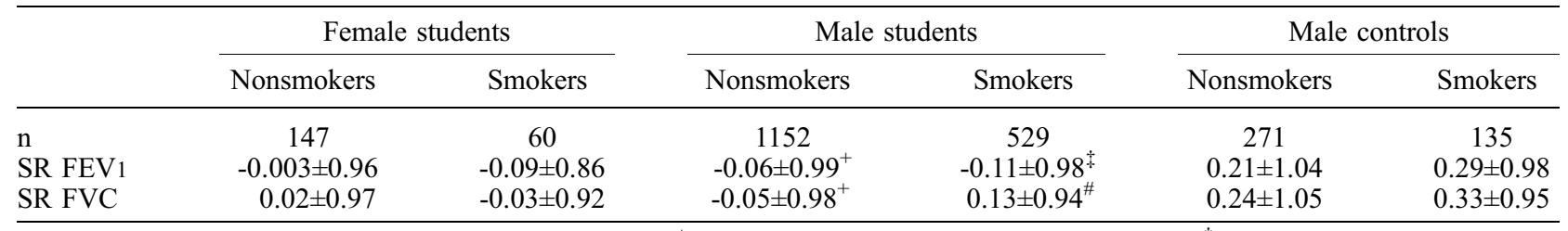

Data are presented as mean $\pm \mathrm{SD}$, except where indicated. ${ }^{+}: \mathrm{p}<0.0001$ groups $v s$. nonsmoking controls; ${ }^{\star}: \mathrm{p}<0.0001$ group $v s$. smoking controls; ${ }^{\#}$ : $\mathrm{p}=0.032$ group $v$ s. smoking controls. 
Table 8. - Factors significantly associated with reduced standardized residuals (SR) for forced expiratory volume in one second (FEV1) and forced vital capacity (FVC) in the cohort. Multiple linear regression analysis

\begin{tabular}{|c|c|c|c|c|c|c|}
\hline & \multicolumn{2}{|c|}{ Female students } & \multicolumn{2}{|c|}{ Male students } & \multicolumn{2}{|c|}{ Male controls } \\
\hline & SR FEV1 & SR FVC & SR FEV1 & SR FVC & SR FEV1 & SR FVC \\
\hline Asthma & - & - & $\begin{array}{c}-0.06 \\
(0.027)\end{array}$ & - & - & - \\
\hline Hyperreactivity & - & - & $\begin{array}{c}-0.44 \\
(0.082)\end{array}$ & - & $\begin{array}{c}-0.46 \\
(0.187)\end{array}$ & $\begin{array}{c}-0.42 \\
(0.188)\end{array}$ \\
\hline Siblings with allergy & - & - & - & - & - & $\begin{array}{c}-0.29 \\
(0.148)\end{array}$ \\
\hline Working with cattle & - & - & - & - & - & $\begin{array}{c}-0.23 \\
(0.117)\end{array}$ \\
\hline
\end{tabular}

Data are presented as regression coefficients with standard errors in parenthesis. All factors in the final model are shown.

distinction is the difference in the duration of exposure in swine confinement buildings (mean yrs of farming: 38-48 yrs [31] versus $2.5-3.9$ yrs (present study)). In the control group, working with cattle was associated to reduced SR for FVC. The interpretation of this finding is difficult but it might reflect a healthy worker selection. Persons that have grown up in rural areas and have experienced lung symptoms while occasionally tending cattle are not likely to choose a farming career. As a consequence they might be highly represented in the control group, selected among rurals with no intention of a farming career

None of the positive STP reactions to allergens known to be abundant in rural areas were associated with reduced lung function. This finding is consistent with data from other studies $[52,53]$. As opposed to these nonspecific indicators of atopy, specific immunoglobulin (Ig)E antibody to house dust mite seems to be an independent predictor of reduced lung function [54].

In conclusion the present study of young farming students with minor working experience did not demonstrate any association between farming exposure and lung symptoms or lung function. Baseline lung function was slightly reduced in male farming students, and among the smoking students with self-reported asthma the reduction was substantial. This might be due to a work-related exposure to agents with inflammatory potential that either alone or in connection with smoke leads to airway inflammation/obstruction.

\footnotetext{
Acknowledgements. The authors wish to thank the farming students and the control subjects for their patience and enthusiasm, and the staff of the farming schools for their continuous support.
}

\section{References}

1. Donham KJ, Popendorf WJ. Ambient air levels of selected gases inside swine confinement buildings. Am Ind Hyg $J$ 1985; 46: 658-661.

2. Donham KJ. Association of environmental air contaminants with disease and productivity in swine. Am J Vet Res 1991; 52: 1723-1730.

3. Groves JA, Ellwood PA. Gases in agricultural slurry stores. Ann Occup Hyg 1990; 35: 139-151.

4. Linnainmaa M, Louhelainen K, Eskelinen T. Effect of ventilation on ammonia levels in cowhouses. Am Ind Hyg Assoc J 1993; 54: 678-682.
5. Virtanen T, Mäntyjärvi RA. Airborne allergens and their quantification and effect on the development of allergy in occupational environments. Appl Occup Environ Hyg 1994; 9: 65-70.

6. Virtanen T, Eskelinen T, Husman K, Mäntyjärvi R. Longand short-term variability of airborne bovine epithelial antigen concentration in cowsheds. Int Arch Allergy Immunol 1992; 98: 252-255.

7. Heederik D, Brouwer R, Biersteker K, Boleij JSM. Relationship of airborne endotoxins and bacteria levels in pig farms with the lung function and respiratory symptoms in farmers. Int Arch Occup Environ Health 1991; 62:595-601.

8. Cormier Y, Tremblay G, Meriaux A, Brochu G, Lavoie J. Airborne microbial contents in two types of swine confinement buildings in Quebec. Am Ind Hyg Assoc J 1990; 44: 537-541.

9. Rask-Andersen A, Malmberg P, Lundholm M. Endotoxin levels in farming. Br J Ind Med 1989; 46: 412-416.

10. Preller L, Heederik D, Boleij JSM, Vogelzang PFJ, Tielen MJM. Lung function and bronchial respiratory symptoms of pig farmers: focus on exposure to endotoxins and ammonia and use of disinfectants. Occup Environ Med 1995; 52: 654-660.

11. Kaukonen K, Savolainen J, Viander M, Kotimaa M, Terho EO. IgG and IgA subclass antibodies against $\mathrm{As}$ pergillus umbrosus in farmer's lung disease. Clin Exp Allergy 1993; 23: 851-856.

12. Malmberg P, Rask-Andersen A, Rosenhall L. Exposure to microorganisms associated with allergic alveolitis and febrile reactions to mold dust in farmers. Chest 1993; 103 : 1202-1209.

13. van Hage-Hamsten M, Johansson E, Wirén A, Johansson SGO. Storage mites dominate fauna in Swedish barn dust. Allergy 1991; 46: 142-146.

14. Iversen M, Korsgaard J, Hallas T, Dahl R. Mite allergy and exposure to storage mites and house dust mites in farmers. Clin Exp Allergy 1990; 20: 211-219.

15. Malmberg P, Rask-Andersen A, Høglund S, KolmodinHedman B, Guernsey JR. Incidence of organic dust toxic syndrome and allergic alveolitis in Swedish farmers. Int Arch Allergy Appl Immunol 1988; 87: 47-54.

16. Iversen M, Dahl R, Korsgaard J, Hallas T, Jensen EL. Respiratory symptoms in Danish farmers: an epidemiological study of risk factors. Thorax 1988; 43: 872-877.

17. Cuthbert OD, Jeffrey IG, McNeill HB, Wood J, Topping MD. Barn allergy among Scottish farmers. Clin Allergy 1984; 14: 197-206.

18. Heinonen OP, Horsmanheimo M, Vohlonen I, Terho EO. Prevalence of allergic symptoms in rural and urban populations. Eur J Respir Dis 1987; 71 (Suppl. 152): 64-69. 
19. Heller RF, Hayward DM, Farebrother MTB. Lung function of farmers in England and Wales. Thorax 1986; 41: $117-121$.

20. Rautalahti M, Terho EO, Vohlonen I, Nuutinen J, Husman $\mathrm{K}$, Korhonen O. Effect of indoor feeding season for cattle on lung function of dairy farmers. Eur J Respir Dis 1987; 71: Suppl. 152, 188-196.

21. Donham KJ, Zavala DC, Merchant JA. Respiratory symptoms and lung function among workers in swine confinement buildings. A cross-sectional epidemiological study. Arch Environ Health 1984; 39: 96-101.

22. Choudat D, Goehen M, Korobaeff M, Boulet A, Dewitte JD, Martin MH. Respiratory symptoms and bronchial reactivity among pig and dairy farmers. Scand $J$ Work Environ Health 1994; 20: 48-54.

23. Larsson K, Eklund A, Malmberg P, Belin L. Alterations in bronchoalveolar lavage fluid but not in lung function and bronchial responsiveness in swine confinement workers. Chest 1992; 101: 767-774.

24. Varslot M, Hilt B, Qvenild T, Langseth M. Pulmonary function in Norwegian farmers keeping domestic animals. Tidskr Nor Laegeforen 1996; 116: 1077-1080. (In Norwegian, English abstract.)

25. Cormier Y, Boulet L-P, Bedard G, Tremblay G. Respiratory health of workers exposed to swine confinement buildings only or both swine confinement buildings and dairy farms. Scand J Work Environ Health 1991; 17: 269275.

26. Zhou C, Hurst TS, Cockcroft DW, Dosman JA. Increased airways responsiveness in swine farmers. Chest 1991; 99: 941-944.

27. Zejda JE, Hurst TS, Rhodes CS, Barber EM, McDuffie HM, Dosman JA. Respiratory health of swine producers focus on young workers. Chest 1993; 103: 702-709.

28. Bongers P, Houthuijs D, Remijn B, Brouwer R, Biersteker $\mathrm{K}$. Lung function and respiratory symptoms in pig farmers. Br J Ind Med 1987; 44: 819-823.

29. Iversen M, Dahl R, Jensen EJ, Korsgaard J. Lung function and bronchial reactivity in farmers. Thorax 1989; 44: 645-649.

30. Donham KJ, Reynolds SJ, Whitten P, Merchant J, Burmeister L, Popendorf WJ. Respiratory dysfunction in swine production facility workers: dose-response relationships of environmental exposures and pulmonary function. Am J Ind Med 1995; 27: 405-418.

31. Schwartz DA, Donham KJ, Olenchock SA, et al. Determinants of longitudinal changes in spirometric function among swine confinement operators and farmers. Am J Respir Crit Care Med 1995; 151: 47-53.

32. Iversen M, Brink O, Dahl R. Lung function in a five-year follow-up study of farmers. Ann Agric Environ Med 1994; 1: 39-43.

33. British Medical Council. Definition and classification of chronic bronchitis for clinical and epidemiological purposes. Lancet 1965; i: 775-777.

34. American Thoracic Society. Standardization of spirometry. Am Rev Respir Dis 1979; 119: 831-838.

35. Yan K, Salome C, Woolcock AJ. Rapid method for measurement of bronchial responsiveness. Thorax 1983; 38: $760-765$.

36. Miller MR, Sigsgaard T. Prevention of thermal and condensation errors in pneumotachographic recordings of the maximal forced expiratory manoeuvre. Eur Respir $J$ 1994; 7: 198-201.
37. Anderson HR, Pottier AC, Strachan DP. Asthma from birth to age 23; incidence and relation to prior and current atopic disease. Thorax 1992; 47: 537-542.

38. David MM, Hanrahan JP, Carey V, Speizer FE, Tager IB. Respiratory symptoms in urban Hispanic and non-Hispanic white women. Am J Respir Crit Care Med 1996; 153: 1285-1291.

39. Neukirch F, Pin I, Knani J, et al. Prevalence of asthma and asthma-like symptoms in three French cities. Respir Med 1995; 89: 685-692.

40. Yunginger JW, Reed CE, O'Connell EJ, Melton LJ, O'Fallon WM, Silverstein MD. A community-based study of epidemiology of asthma. Incidence rates, 1964-1983. Am Rev Respir Dis 1992; 146: 888-894.

41. Larsson L. Incidence of asthma in Swedish teenagers: relationship to sex and smoking habits. Thorax 1995; 50: 260-264.

42. Vesterinen E, Kaprio J, Koskenvou M. Prospective study of asthma in relation to smoking habits among 14729 adults. Thorax 1988; 43: 534-539.

43. Torén K, Brisman J, Järvholm B. Asthma and asthma-like symptoms in adults assessed by questionnaires a literature review. Chest 1993; 104: 600-608.

44. Quanjer PhH, Tammeling GJ, Cotes JE, Pedersen OF, Peslin R, Yernault J-C. Lung volumes and forced ventilatory flows. Official statement of the European Respiratory Society. Eur Respir J 1993; 6: Suppl. 16, 5-40.

45. Sigsgaard T, Hjort C, Omland Ø, Miller MR, Pedersen OF. Respiratory health and allergy among young farmers and non-farming rural males in Denmark: the SUS study. J Agromed 1997; 4: 68-73.

46. Vergnenegre A, D'arco X, Melloni B, et al. Work related distal airway obstruction in an agricultural population. Occup Environ Med 1995; 52: 581-586.

47. Fletcher CM, Peto R. The natural history of chronical airflow obstruction. BMJ 1977; 1: 1645-1648.

48. Rijcken B, Schoutn JP, Weiss ST, Speizer FE, van der Lende R. The relationship between airway responsiveness to histamine and pulmonary function level in a random population sample. Am Rev Respir Dis 1988; 137: 826832.

49. Cockcroft DW, Killian DN, Mellon JJA, Hargreave FE. Bronchial reactivity to inhaled histamine: a method and clinical survey. Clin Allergy 1977; 7: 235-243.

50. Minette A, Mercq M, Gepts L. Prognostic value of positive acetylcholine test regarding $\mathrm{VC}$ and FEV1 in coalminers with history of chronic bronchitis. Bull Eur Physiopathol Respir 1978; 14: 167-175.

51. Kauffmann F, Neukirch F, Korobaeff M, Marne MJ, Claud JR, Lellouch J. Eosinophils, smoking and lung function. An epidemiological survey among 912 working men. Am Rev Respir Dis 1986; 104: 1172-1175.

52. Taylor RG, Joyce H, Gross E, Holland F, Pride NB. Bronchial reactivity to inhaled histamine and annual rate of decline in FEV1 in male smokers and ex-smokers. Thorax 1985; 40: 9-16.

53. Vollmer WM, Buist AS, Johnson LR, McCamant LE, Halonen M. Relationship between serum IgE and crosssectional and longitudinal FEV1 in two cohort studies. Chest 1986; 90: 416-423.

54. Omenaas E, Bakke P, Eide GE, Elsayed S, Gulsvik A. Serum house-dust-mite and reduced FEV1 in adults of a Norwegian community. Am J Respir Crit Care Med 1995; 152: $1158-1163$. 